\title{
Moving beyond water centricity? Conceptualizing integrated water resources management for implementing sustainable development goals
}

\author{
David Benson ${ }^{1}$ - Animesh K. Gain ${ }^{2}$ (1) . Carlo Giupponi ${ }^{3}$
}

Received: 14 May 2018 / Accepted: 4 September 2019

○) Springer Japan KK, part of Springer Nature 2019

\begin{abstract}
While the UN's 2030 Agenda for Sustainable Development, adopted in 2015, establishes an ambitious set of goals, targets and indicators for supporting global sustainability, greater conceptual clarity is required to measure implementation. A key UN Target (6.5) for implementing sustainable development goal (SDG) 6 is to 'implement integrated water resources management (IWRM) at all levels'. However, we argue that the current UN emphasis on measuring its implementation through institutional indicators limits our understanding of effectiveness, while ignoring links to other SDGs. While IWRM is often interpreted to mean the integration of water-related management components at the river basin scale, conceptualizations differ significantly. Specifying the critical normative principles of IWRM, therefore, becomes important for measuring its implementation. Drawing upon pre-existing conceptualizations, we consequently identify seven core principles or dimensions (integration; scale; institutions; participation; economic valuation; equity; and, environmental/ecological protection) to re-conceptualize IWRM after the adoption of agenda 2030. These dimensions, we argue, allow more objective measurement of IWRM implementation through the development of Target 6.5 sub-indicators. They also help shift IWRM beyond its current 'water centric' emphasis to enhance its contribution to achieving other SDGs such as those for ending poverty, providing clean and affordable energy, achieving gender equality, protecting terrestrial ecosystems, promoting sustainable cities, combatting hunger and climate change, and strengthening the Global Partnership for Sustainable Development.
\end{abstract}

Keywords Integrated water resources management $\cdot$ Sustainable development goals $\cdot$ Goal $6 \cdot$ Target $6.5 \cdot$ Indicators

\section{Introduction}

Handled by Osamu Saito, United Nations University Institute for the Advanced Study of Sustainability, Japan.

Animesh K. Gain

gain@geographie.uni-kiel.de

David Benson

d.i.benson@exeter.ac.uk

Carlo Giupponi

cgiupponi@unive.it

1 Department of Politics, The Environment and Sustainability Institute, University of Exeter, Penryn Campus, Cornwall, UK

2 Coastal Risks and Sea-Level Rise Research Group, Department of Geography, Christian-Albrechts-University of Kiel, Ludewig-Meyn-Str. 14, 24098 Kiel, Germany

3 Department of Economics, Ca' Foscari University of Venice, Cannaregio, 873, Venice, Italy
The UN's sustainable development goals (SDGs) inform the implementation of the 2030 Agenda for Sustainable Development, adopted in 2015 (UN 2017). In contrast to their predecessors, the millennium development goals (MDGs), the SDGs adopt a more holistic 'triple bottom line' approach to sustainable development that integrates environmental and socio-economic objectives (Sachs 2012). The SDGs additionally encompass multiple 'wicked' (DeFries and Nagendra 2017) environmental issues, including water pollution, climate change, unsustainable consumption and degradation of marine resources. The 17 goals are each accompanied by specific targets, 169 in total, and supported by 232 indicators for monitoring progress (UN 2017). Although these targets and indicators will play a significant role in measuring and cross-national benchmarking SDG effectiveness, this article argues that they require refining to alleviate 'conceptual stretching' 
(Sartori 1970) and better support the implementation of Agenda 2030.

Sustainable development has always been a debated concept, subject to multiple meanings (Baker 2016). Originally defined in the Brundtland Commission's report, Our Common Future, as development 'that meets the needs of the present without compromising the ability of future generations to meet their own needs' (WCED 1987), sustainable development has evolved to become a key objective for policy-makers at multiple levels despite ambiguity over its exact interpretation (Baker 2016; Mebratu 1998; Redclift 2005). A requirement for precise indicators to guide sustainable development implementation globally was, therefore, identified in Chapter 40 of Agenda 21, adopted by the UN Rio Earth Summit in 1992 (UNCED 1992). Yet, the intervening period has witnessed the emergence of a multiplicity of essentially non-comparable measures of sustainable development adopted in different governance contexts [see for example, Rennings and Wiggering (1997), Robert et al. (2005) and Steurer and Hametner (2013)], thereby necessitating the generation of relevant SDG indicators so that clear and unambiguous messages be conveyed to users (Hák et al. 2016). In this respect, there were obvious attempts by their drafters, the UN Inter-Agency and Expert Group on Sustainable Development Goal Indicators (IAEG-SDGs), to ensure the relevance of SDG indicators. On closer inspection, however, some SDG indicators seemingly rely on the uncritical specification of potentially irreducibly normative concepts that, in the absence of further definitional clarity, could limit useful data collection and quantification of progress.

Several examples of this definitional problem come from goal 6 ['Ensure availability and sustainable management of water and sanitation for all' (UN 2017)]. Targets and attendant indicators within this goal appear strongly 'relevant,' but it is less certain that they are entirely objective, with attendant consequences for measurability and comparability. For example, Target 6.1 refers to ensuring access to drinking water, while stating that such access should be 'equitable' and 'affordable' (UN 2017). While each of these terms is open to context-specific interpretation, the requisite indicator (6.1.1) measures target attainment through the '[p]roportion of population using safely managed drinking water services' (UN 2017). Clear questions arise over what constitutes the safety of management, equity of distribution and affordability, concerning costs to users of a basic human right such as water. Other inconsistencies are evident in Target 6.b, which is aimed at supporting and strengthening local community participation in managing water and sanitation. The term 'participation' is another generic and vague practice, debated in some cases but more often misused within water management globally (Mauerhofer 2016; Ruiz-Villaverde and García-Rubio 2017).
But perhaps the most significant concern relates to Target 6.5 for implementing 'integrated water resources management (IWRM) at all levels' (UN-Water 2017a; UN-Water 2018). Definitions abound; however, the most popular conception is provided by the GWP (2017) in which IWRM is understood as 'a process which promotes the coordinated development and management of water, land and related resources to maximize economic and social welfare in an equitable manner without compromising the sustainability of vital ecosystems'. Under Target 6.5, IWRM is measured by the degree of national institutional implementation and, in transboundary basins, the proportion of area subject to cooperation (UN-Water 2017a; UN-Water 2018). In other words, the indicators are based largely on institutional development, which, while relatively straightforward to measure, fail to recognize the multifaceted nature of IWRM as a process. In this respect, integrated water resources management is often practically interpreted to mean the integration of waterrelated management components at the river basin scale, although is far from a unified concept (Gain et al. 2017; Hering and Ingold 2012; OECD 2018; Rouillard et al. 2014). In addition, due to its sectoral cross-cutting nature, IWRM has the potential to not only support the achievement of SDG 6 but also other non-water related SDGs, by moving beyond its current water centric focus to recognize the importance of water resources to wider sustainable development (Pires et al. 2017). However, as UN Target 6.5 does not provide a conceptual interpretation of IWRM based on its normative principles, tracking its contribution to SDG implementation using current indicators will be difficult (Bartram et al. 2018; Bhaduri et al. 2016). Several critical questions, therefore, arise for SDG implementation, including: 'how can Target 6.5 be quantitatively and objectively assessed and monitored using key principles of IWRM?' and 'how can Target 6.5 implementation support the wider SDGs?'.

The objective of this article is, therefore, to re-conceptualize IWRM, with an aim to objectively measure the progress of SDG 6.5 but also broaden the contribution of this management approach to associated SDGs such as: ending poverty (SDG 1); zero hunger (SDG 2); achieving gender equality (SDG 5); promoting sustainable cities (SDG 11); combatting climate change (SDG 13); protecting life on earth (SDG 15); promoting inclusive societies and accountable institutions (SDG 16); and supporting global partnerships (SDG 17). Drawing on pre-existing conceptions of IWRM and published studies, we, therefore, identify seven core IWRM normative, principled 'dimensions' as the basis of a revised set of SDG 6.5 indicators specifically for this purpose, namely: integration; scale; institutions; participation; economic valuation; equity; and environmental/ ecological protection. These dimensions, we argue, allow more objective measurement of IWRM through guiding the development of sub-indicators for data collection and 
comparative quantification of its implementation by 2030 , along with assessments of the contribution of IWRM to achieving other SDGs.

\section{Measuring IWRM for SDG implementation: from institutions to process principles?}

In our opinion, Target 6.5 of the UN SDGs is one of the most ambiguous of all the SDG targets mainly for two reasons. One of the reasons is the overt emphasis on measuring institutional uptake inherent in its key indicators. Another is the limited consideration of IWRM as a process, based upon integrating multiple water use components within an overall management approach, in measuring target attainment.

In respect of the first point, two indicators are identified by the UN to monitor the progress of SDG 6.5: (a) '6.5.1-Degree of integrated water resources management [IWRM] implementation'; and (b) '6.5.2-Proportion of transboundary basin area with an operational arrangement for water cooperation' (UN-Water 2017a; UN-Water 2018). Using a self-assessment survey approach, indicator 6.5.1 measures four components of IWRM-an enabling environment, institutions, management tools, and financing (UN-Water 2017c). According to Bertule et al. (2018), the survey-based approach presents inherent challenges related to subjectivity, lack of transparency and comparability of the results. Without operationalizing the IWRM concept, the assessment of the status of policies/laws/plans, institutions, management instruments and financing is highly subjective. Problematically, the survey questionnaire on the enabling environment, institutions, management tools and financing for IWRM can generate different meanings to different groups of stakeholders. In addition, through analyzing the methodology for assessing SDG indicator 6.5.2 (UN-Water 2017b; McCracken and Meyer 2018) show how the normative and binary nature of the indicator obscures the political complexity of establishing a cooperative process. Consequently, this indicator provides a false depiction of the extent of cooperation that is occurring over shared waters (UNWater 2017b; McCracken and Meyer 2018). They also argue that there is a strong bias to using surface area as a metric to assess cooperation, resulting in weighting larger basins and aquifers over smaller basins in the calculation of the 6.5.2 indicator. McCracken and Meyer (2018), therefore, suggest possible adaptations of the indicator design to better assess transboundary water cooperation.

In relation to the second point, we argue that the selected indicators of SDGs (UN-Water 2018) do not reflect important operational principles of IWRM as a management process, such as sectoral integration, public participation, equity and environmental sustainability. That said, an evident problem for alternative indicator development is the lack of an agreed conceptualization of IWRM. According to Grigg (2014), Biswas (2008) and Saravanan et al. (2009), the IWRM concept is vague and characterized by an allinclusive character and flexibility, which results in multiple interpretations. Until recently, the main barrier to successful IWRM implementation has been the lack of theoretical and conceptual clarity (Acheampong et al. 2016). As a result, there is generally weak evidence linking the means of IWRM implementation to the outcomes of SDG 6.5 (Bartram et al. 2018). Without providing conceptual clarity on precisely 'what is IWRM?', achieving its effective implementation on a global scale may consequently prove unrealistic.

\section{Conceptualization through comparative analysis}

Therefore, one evident feature of IWRM is its conceptual malleability due to diverse notions and meaning of the term (Biswas 2008). Such forms of managing water resources can trace their historical roots back through several centuries of various holistic water management practices (see Molle 2009). Modern derivations of IWRM can be dated to the UN Mar del Plata Conference 1977 and subsequently the 1992 Dublin International Conference on Water and the Environment (ICWE) (Biswas 2004). The Dublin Principles adopted at the Conference (ICWE/WMO 1992) have informed the diffusion of IWRM globally. Here, IWRM is interpreted as constituting four normative principles related to the finite and vulnerable nature of water resources, the development and management of waters based upon a participatory approach, the inclusion of women in decisionmaking and the recognition of water as an economic good (ICWE/WMO 1992).

\section{Conceptual expansion}

IWRM has become subject to significant expansion of its conceptual parameters within international and national water policy norms, with the term now used interchangeably to denote a variety of water governance models (Gain et al. 2017). Indeed, as a result of its global diffusion, IWRM now constitutes the dominant paradigm for water management globally (Allouche 2016), although retains its overt water centricity, which led to recent academic and policy discussion around alternative, holistic resource management concepts such as the water-energy-food (WEF) nexus (Benson et al. 2015). The most prominent process-oriented guidance for implementing the IWRM paradigm is provided by the Global Water Partnership (GWP 2009), which has established a 'toolkit' based upon a checklist of actions: establishing river basin management systems; defining the roles of river basin organisations; mobilizing finance; ensuring 
stakeholder participation; strategic planning and developing management action plans; establishing monitoring and information systems; and communication. UNESCO also has produced guidelines for IWRM implementation at the river basin level (UNESCO 2009). Key principles of IWRM identified include adoption of:

'... a step-by-step process of managing water resources in a harmonious and environmentally sustainable way by gradually uniting stakeholders and involving them in planning... while accounting for evolving social demands due to such changes as population growth, rising demand for environmental conservation, changes in perspective of the cultural and economic value of water, and climate change.' (UNESCO 2009: 3)

In relation to these guidance sources, the OECD (2018) provides a set of indicators for water governance based on 12 principles, grouped within three dimensions: effectiveness; efficiency; trust and engagement. Although overtly governance oriented, the indicators can also support IWRM through measuring governance gaps and policy priorities in the implementation of SDG 6 (OECD 2018: 6).

As a result of this conceptual flexibility at the global level, IWRM has been interpreted differently in implementation, according to governance context (e.g., Giordano and Shah 2014). For example, the European Union (EU) has implemented IWRM via its Water Framework Directive, which legally obliges the Member States to adopt river basin management planning (Official Journal of the European Communities 2000). The EU has actively sought to export this model globally, leading to transnational polycentricism and hybridization around this IWRM approach in non-EU contexts (Fritsch et al. 2017). Watershed planning is well-established in the USA, with current government guidance overtly endorsing an IWRM approach to addressing non-point source pollution through participative management planning (EPA 2008). Meanwhile, IWRM continues to inform water governance across Southern countries, with the GWP providing multiple national case studies (GWP 2009). Academic studies have recorded various aspects of IWRM implementation, for example in the Caucasus and Central Asia (Sokolov 2006), Africa (Agyenim and Gupta 2012; Ako et al. 2010; Movik et al. 2016; Nigatu Mersha et al. 2015), Asia (Mehtonen et al. 2008; Varis et al. 2008; Yu et al. 2016), the Caribbean (Senecal and Madramootoo 2013) and South America (Calizaya et al. 2010; Libanio 2014; Lorz et al. 2012). That said, a recurring criticism of IWRM is that its top-down technocratic approach to water governance presents challenges to developing countries, where cultural, economic and political contexts may preclude practical application (Al-Saidi 2017a; Beveridge and Monsees 2012; Biswas 2004; Butterworth et al. 2010).

\section{Re-conceptualising IWRM}

Without careful consideration this diversity in practical interpretation could well inhibit the use of IWRM implementation as an objective indicator for comparative SDG analysis. In view of this, we identify seven principles of IWRM based on international norms (GWP 2009, UNESCO 2009, OECD 2018), national implementation studies, and our earlier research (Benson et al. 2015; Gain et al. 2017; Gain et al. 2013; Giupponi and Gain 2017; Rouillard et al. 2014). These seven core principles or 'dimensions' can be abstracted to inform conceptual sub-indicators, as composite measures of SDG 6.5. implementation (Fig. 1). Each dimension can also potentially be employed to measure how IWRM is supporting other SDGs through the use of dedicated indicators (Table 1).

First, is the notion of the integration of water management. This aspect strongly relates to the social, economic and environmental pillars inherent in mainstream definitions of sustainable development (Baker 2016), as reflected in the Dublin Principles which refer to the need for 'a holistic approach, linking social and economic development with protection of natural ecosystems' (ICWE/WMO 1992). The GWP (2009) recommends, as an initial step, development of a river basin management strategy that links to broader development objectives. Basin management plans, it is recommended, should recognize environmental needs as well as socio-economic considerations (GWP 2009). Similarly, UNESCO (2009) identifies the 'importance of sectoral perspectives' in IWRM planning. For achieving such integration, measuring physical parameters such as the availability, quality and safety of water resources is initially required (UNESCO 2009). While often difficult to practically achieve, integration could, therefore, be measured through several indices such as water scarcity indices, water quality indices and flood risk indices, as well as IWRM outputs, primarily planning (Gain et al. 2016). For example, EU Water Framework Directive river basin management plans must demonstrate the integration of multiple water use objectives, implementing them under a programme of measures (Voulvoulis et al. 2017). To provide linkage to other SDG Targets (UN 2017), such an indicator could also include, for example, measurements of water allocations for food production (e.g., Target 2.3 for increasing agricultural productivity and producer incomes), renewable energy production such as hydropower or biofuel crops (goal 7), and terrestrial ecosystems protection (goal 15: see below). Important links could also be established between an IWRM integration indicator and sustainable provision of urban water services (goal 11) and thereby helping reduce mortality from water borne diseases (goal 3), and strengthening adaptation capacity for climate change (goal 13). Data availability for measuring integration could also be linked to SDG 17 (for strengthening the Global 


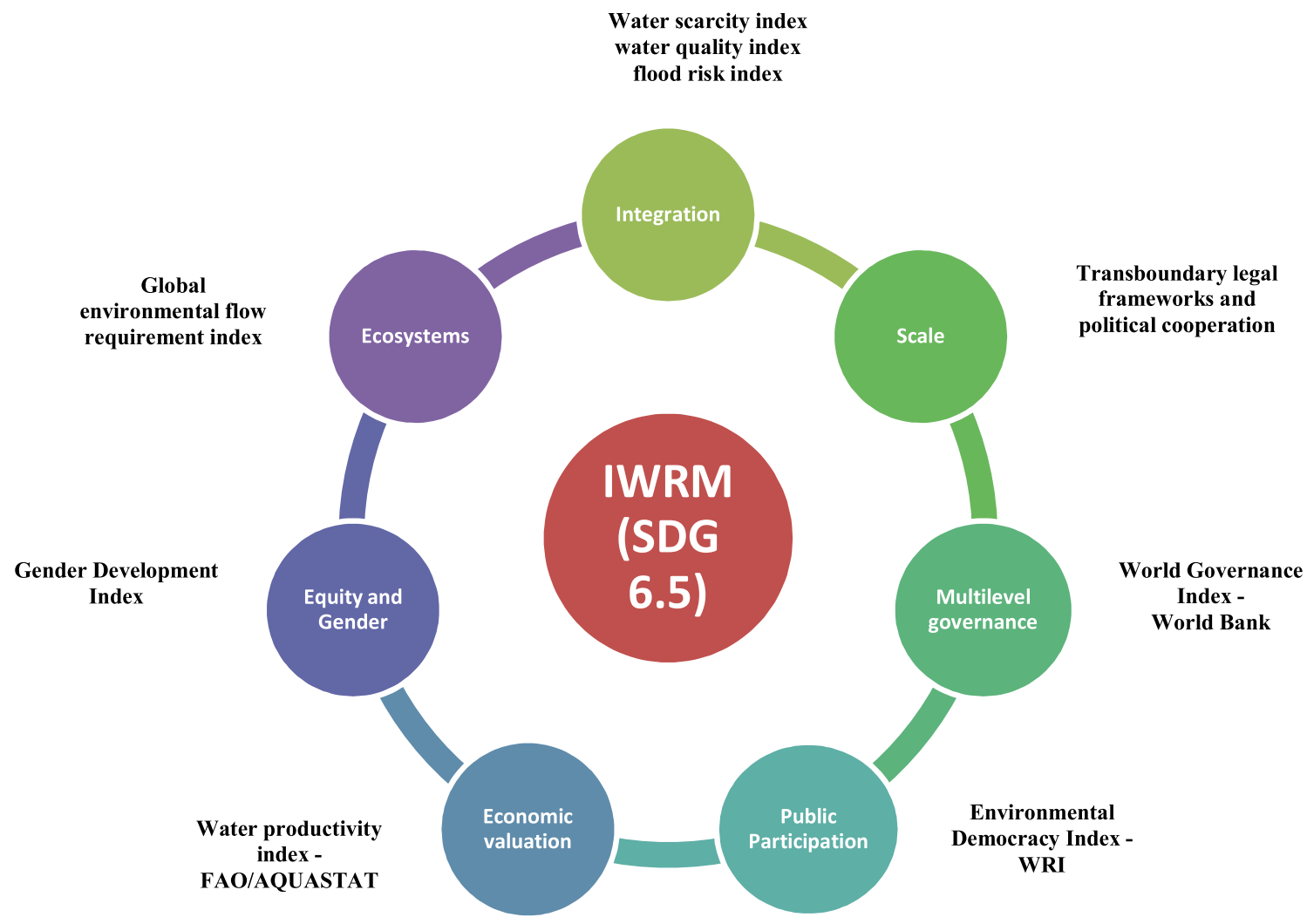

Fig. 1 Seven dimensions of integrated water resources management along with suggested indicators for measuring SDG 6.5 globally. Each circle indicates a specific dimension of IWRM and each rectangle represents suggested indicators for global assessment of the dimension

Table 1 Summary of IWRM dimensions, potential indicators and links to SDGs

\begin{tabular}{llc}
\hline IWRM dimension & Indicators & SDG links \\
\hline Integration & Water Security Index (Gain et al. 2016) & SDG 2, SDG 3, SDG 7, SDG 11, \\
& & SDG 15, SDG 17 \\
Scale & River basin or watershed scale (Farinosi et al. 2018; De Stefano et al. 2017) & SDG 16 \\
Institutions & World Governance Index (Kaufmann et al. 2010); Indicators of regulatory policy & SDG 16 \\
& $\quad$ and governance (Arndt et al. 2015) & \\
Participation & $\begin{array}{l}\text { Environmental Democracy Index (WRI 2018); Participation effectiveness (Koch- } \\
\text { skämper et al. 2016) }\end{array}$ & SDG 5, SDG 10, SDG 16, SDG 17 \\
Economic value & Water pricing (Sjödin et al. 2016); water productivity index (Giupponi et al. 2018; & SDG 12, SDG 17 \\
& $\quad$ Molden et al. 2010) & \\
Equity & Gini coefficient; Gender development index (Klasen and Schüler 2011); Environ- & SDG 1, SDG 5, SDG 10 \\
& ment and Gender Index & SDG 3, SDG 13, SDG 15
\end{tabular}

Partnership for Sustainable Development) through technology cooperation and capacity-building.

Second, the Dublin Principles introduced a subsidiarity component to IWRM, whereby decision-making should be devolved to the lowest institutional level or scale, i.e., river basins. This aspect reflects the emphasis placed upon different levels, including local and regional, by Agenda 21 in delivering sustainable development (UNCED 1992). Both the GWP (2009) and UNESCO (2009) predicate their IWRM models on the river basin scale considering transboundary issues and conflicts, while the OECD governance indicators recognize that water should be managed at the 'appropriate scale(s) within basin systems, to reflect local conditions, and foster co-ordination' (OECD 2018). While 
this aspect could be measured through institutional adoption, as currently undertaken for SDG Indicator 6.5.1, transboundary river basin management is quantifiable using, for example, an institutional indicator for transboundary legal frameworks and political cooperation, as available in the Transboundary Water Assessment Programme (see De Stefano et al. 2017; Gain et al. 2016; Munia et al. 2016; Zeitoun et al. 2013). This dimension could also be linked to parallel SDG Targets, including 16.7 (for ensuring 'responsive, inclusive, participatory and representative decision-making at all levels' (UN 2017: 22) and goal 16 more generally, to show how IWRM is contributing to subsidiarity in other goal attainment.

Third, management of water resources occurs within a nested hierarchy of multi-level governance (Rouillard et al. 2014), supported by national and local institutions (as rules and/or organizations). The GWP (2009) recommend development of river basin organizations (RBOs) for managing IWRM, within an overarching institutional framework. In this respect, $80 \%$ of countries globally have now adopted an institutional framework for IWRM: as currently measured by Target 6.5 and indicator 6.5.1 (UNEP 2018). Moreover, a variety of river basin organizations, with different institutional configurations, have been established in multiple IWRM contexts (e.g., Huitema and Meijerink 2014; GWP 2009). However, simply measuring national or local legal implementation gives little indication of institutional effectiveness. Rather than using the current UN focus on the adoption of institutional arrangements for IWRM, a better proxy indicator for measuring 'good' governance more broadly is the World Governance Index developed by the World Bank (Kaufmann et al. 2010), or 'indicators of regulatory policy and governance' developed by the Organisation for Economic Co-operation and Development (Arndt et al. 2015). Such indicators would also support the implementation of SDG 16 targets which call for more effective, accountable and inclusive institutions for meeting the 2030 goals (UN 2017).

Fourth, IWRM is commonly associated with public participation, including that of women, in decision-making, although approaches vary significantly (Benson et al. 2015). Participation is a recommended element for IWRM processes in multiple guidelines (GWP 2009; UNESCO 2009; EPA 2008), while is mandatory for river basin management planning under the EU Water Framework Directive (Jager et al. 2016; Kochskämper et al. 2016; Newig et al. 2016) and many national IWRM systems worldwide. Public participation in IWRM has been studied in various contexts, including China (Yu et al. 2014), Tanzania (Dungumaro and Madulu 2003), Mexico (Wester et al. 2009), Zimbabwe (Fatch et al. 2010), Sri Lanka and Bangladesh (Evans and Varma 2009), and Ghana (Poolman and Van De Giesen 2006). Indicative measures of participation vary accordingly between IWRM systems. One means of quantitatively assessing participation could involve separating process from outcomes: the input of non-state actors to management planning can be quantitatively assessed alongside the extent to which plan objectives reflect their wishes. For example, Kochskämper et al. (2016) measure participation effectiveness for governance through four mechanisms: the 'opening up of decision-making to environmental concerns'; 'incorporation of additional environmental knowledge'; 'dialogical interaction'; 'acceptance, implementation and compliance' of decisions taken. A proxy indicator such as the Environmental Democracy Index, developed by the World Resource Institute (WRI 2018), could also be used for measuring this dimension. Measuring IWRM participation through an indicator would also provide linkage to other SDG Targets including 16.7 for inclusive decision-making and also 17.17 , that seeks to promote 'effective public, public-private and civil society partnerships' (WRI 2018). Links could also be made to SDG 5 for enhancing gender equality and empowerment of women (see below), in addition to SDG 10 for reducing societal inequality, particularly Targets 10.2 and 10.3. Indeed, given that participation is a normative principle inherent in the Brundtland conception of sustainable development (WCED 1987; Baker 2016), IWRM could become a powerful mechanism for supporting sustainability governance generally.

Fifthly, recognition of the economic value of water is also central to the Dublin Principles: an assessment feature subsequently incorporated into IWRM systems globally (Gain et al. 2017). The EU Water Framework Directive, for example, explicitly requires 'economic analysis of water use' as part of the characterization of water resources (Official Journal of the European Communities 2000: 11). In addition, Member States are obliged to take account of the principle of recovery of the costs of water services, including environmental and resource costs', with contributions to the recovery of costs made by all water users (Official Journal of the European Communities 2000: 12-13). Water pricing can, therefore, contribute to effective resource management through enhancing efficiency, as demonstrated in Australia and South Africa (Sjödin et al. 2016). That said, the effectiveness of economic valuation (Giupponi et al. 2018) and water pricing has been questionable in IWRM, particularly in the EU (see EurEau 2016). In a review by Toan (2016) found that developed nations including EU have been promoting full supply cost recovery, while subsidies are still important in both developing and developed countries. The developing countries are gradually moving toward efficiency-oriented water-pricing policies. The examples include water as a private good in Morocco (Faysse et al. 2010), water-pricing methods in irrigation services in Bangladesh (Mottaleb et al. 2019), China (Wang and Chen 2014) and India (Veettil et al. 2011), urban water pricing in 
Yemen (Al-Saidi 2017b) and Kenya (Fuente et al. 2016). The best proxy for measuring economic value is a water productivity index $\left(€ / \mathrm{m}^{3}\right.$ of water), which is available in the FAO/AQUASTAT database (Molden et al. 2010). The water productivity index could also be considered for assessing water use efficiency (SDG 6.4.1). An economic value indicator can also strengthen the role of IWRM in 'domestic resource mobilization' for sustainable development identified in SDG Target 17.1, plus ensuring 'sustainable management and efficient use of natural resources' in SDG 12, Target 12.2 (UN 2017).

Sixthly, resource use factors include whether water allocations are equitable, which includes social, political and gender mainstreaming dimensions (Gain et al. 2017). Equity constitutes one of the three pillars of IWRM along with economic efficiency and environmental sustainability (GWP 2017). The social dimension of equity refers that the provision of water services is a basic right to all individuals and no one including poor and marginal people will be excluded from the services (GWP 2011; Jimenez-Redal et al. 2018). The political dimensions include the distribution of power and wealth between different groups and individuals, and the processes that create, sustain and transform these relationships over time (Harris et al. 2011). A typical example is hydro politics associated transboundary water sharing between upstream and downstream countries. A third dimension is gender, which promotes the role of women in water management. As identified above, intergenerational equity is central to the Brundtland definition of sustainable development (WCED 1987) but societal and transnational equity is also critical to its conceptualization. In response, measures such as the Gini coefficient could be used as a general indicator for equity (which includes all three dimensions) in IWRM (Gini 1997), or be applied as a specific indicator for water availability. Many have argued that the concept of sustainable development should also recognize gender equity as a critical focus (for example, Dobson 1996), leading to attempts to mainstream it into sustainable development governance (Baker 2016). Here, Agenda 21 explicitly recognizes the centrality of women in achieving global action (UNCED 1992). The Dublin Principles (ICWE/WMO 1992) also specifically refer to the importance of women in providing, managing and safeguarding water use while also identifying the need for efficient resource use. That said, global IWRM guidelines (GWP 2009; UNESCO 2009) only briefly mention this aspect. Only a few academic studies assess the role and influence of women in IWRM decisionmaking, with limited use made of empirical indicators (for example, Ahmed 2008; Derman and Prabhakaran 2016; Manase et al. 2003). Equity aspects of IWRM could, however, be measured via accessibility of supply indicators, as well as a gender development index (Klasen and Schüler 2011) or the 'Environment and Gender Index'. In addition to SDG 5 (for achieving gender equality and empowering women), this type of indicator would support SDG 1.4 that seeks to ensure "equal rights to economic resources, as well as access to basic services' (UN 2017) in poverty reduction, in addition to SDG Target 10.2 for social, economic and political inclusion.

Finally, the environmental/ecological protection capacity of IWRM is also a key feature. One of the earliest conceptions of sustainable development was introduced by the International Union for the Conservation of Nature and Natural Resources, in its World Conservation Strategy in 1980, with a specific emphasis on ecological conservation (IUCN 1980). The notion of environmental limits, particularly the need for sustainable use of ecological resources, was then incorporated into the Brundtland and UNCED sustainability agendas. Indeed, some argue that ecological sustainability is a central objective of sustainable development as a model of socio-economic change (Lélé 1991). This notion also underpins IWRM implementation guidelines (GWP 2009; UNESCO 2009). Integrating environmental protection objectives into river basin management planning is already undertaken in the EU Water Framework Directive through a requirement to ensure good ecological status of surface waters (Official Journal of the European Communities 2000). Other systems of IWRM also provide a mechanism for protecting ecological resources, as illustrated in Asia, Southern Africa and small island developing states (Leendertse et al. 2008; Saha and Setegn 2015). This ecological protection capacity of IWRM can be quantitatively measured at river basin or catchment scales through, for example, a global environmental flow requirement index (see Pastor et al. 2014; Sood et al. 2017; Arthington et al. 2018), biodiversity indices or measures of ecosystems services (e.g., UNEP-WCMC 2014). In addition to linking with SDG Target 6.6, which specifically seeks to 'protect and restore water-related ecosystems', such an indicator could also be employed to measure how IWRM is contributing to SDG Target 15.1 (UN 2017) for protecting terrestrial and freshwater ecosystems and their service provisions. Other benefits of IWRM measured could include those for human health (SDG 3) from protection of ecological resources (Bunch et al. 2011), and reducing carbon emissions through conserving ecosystems (SDG 13).

\section{Future prospects: moving IWRM out of the water paradigm?}

Implementing the SDGs by 2030 poses significant challenges, most notably how to precisely assess progress across all goals. There are both conceptual and empirical issues, most notably how to measure SDG targets through comparative indicators. Target 6.5 poses particular challenges due to the contested nature of the IWRM concept. In our 
introduction we, therefore, asked how implementation could be measured using key IWRM principles. Our dimensions, we argue, provide a more objective measurement of IWRM through allowing development of sub-indicators for process components based on our dimensions: integration; scale; institutions; participation; economic valuation; equity; and, environmental/ecological protection (see Fig. 1). Conceptually redefining IWRM via such dimensions rather than through institutional adoption potentially allows for the development of robust quantitative indicators that can provide more direct comparison between national implementations or implementations at river basin or watershed scale. We also posed the question in our introduction as to how Target 6.5 could support implementation of other SDGs through such indicators. By linking indicators to non-water focused SDGs, an assessment can be made as to how IWRM is contributing to inter alia, poverty reduction, environmental protection and climate change adaptation.

As a result, two areas could be considered for future academic research and policy development concerning SDG Target 6.5. First, the choice and calibration of improved indicators is a critical consideration for academics, practitioners and policymakers. That said, relevant issues concern technical and financial capacities for data collection and analysis, particularly in the Global South. This problem is to an extent anticipated in SDG 17.18 ('By 2020, enhance capacity-building support to developing countries,... to increase significantly the availability of high-quality, timely and reliable data disaggregated by income, gender, age, race, ethnicity, migratory status, disability, geographic location and other characteristics relevant in national contexts'), whereby it could provide a positive opportunity for developing global partnerships through promoting greater transnational technological cooperation around IWRM data provision and analysis. Rapid advances in big data, machine learning and artificial intelligence are opening up new possibilities for environmental and social scientists in this respect (see WEF 2018). Second, our analysis shows that focusing on integrated water resources management (Target 6.5) can be an important mechanism for achieving other 'non-water' goal s, if its implementation is more widely operationalized and measured in policy responses worldwide. Considering the proposed dimensions of IWRM and its implementation can help support achieving 59 out of 169 targets (Smith and Clausen 2017) of all SDGs including no poverty (SDG 1), zero hunger (SDG 2), gender equality (SDG 5), life on land (SDG 15), peace, justice and strong institutions (SDG 16) and partnerships for the goals (SDG 17) (see Table 1). Fader et al. (2018) also stated that the target 6.5 has no conflicts with other SDGs and it has the high number of potential synergies with other SDGs. Thus, achieving SDG 6.5 will make it continuously easier to achieve other SDG targets. It will also help IWRM, as a governance model, to move away from its current water centric focus to encompass more integrated forms of sustainable development.

Acknowledgements This article was produced as part of the SDG Assessment Core Group of the Sustainable Water Future Programme of Future Earth. All authors would like to acknowledge the anonymous reviewers for their insightful comments. A.G. is financially supported by the cluster of excellence, 'the Future Ocean' that is gratefully acknowledged (Grant no. CP 1778). A.G. also would like to acknowledge Marie Sklodowska-Curie Global Fellowship (Project No. 787419) of the European Commission.

Author contributions D.B. and A.G. designed the research, A.G. identified the indicators and C.G. supported research on the SDGs. All authors equally contributed to the writing and discussions.

\section{References}

Acheampong EN, Swilling M, Urama K (2016) Developing a framework for supporting the implementation of integrated water resource management (IWRM) with a decoupling strategy. Water Policy 18:1317-1333. https://doi.org/10.2166/wp.2016.155

Agyenim JB, Gupta J (2012) IWRM and developing countries: implementation challenges in Ghana. Phys Chem Earth Parts A/B/C 47-48:46-57. https://doi.org/10.1016/j.pce.2011.06.007

Ahmed S (2008) Gender and integrated water resources management in South Asia: the challenge of community-managed alternatives. In: Lahiri-Dutt K, Wasson RJ (eds) Water first: issues and challenges for nations and communities in South Asia. Sage, New Delhi, pp 185-201

Ako AA, Eyong GET, Nkeng GE (2010) Water resources management and integrated water resources management (IWRM) in Cameroon. Water Resour Manag 24:871-888. https://doi.org/10.1007/ s11269-009-9476-4

Al-Saidi M (2017a) Conflicts and security in integrated water resources management. Environ Sci Policy 73:38-44. https:// doi.org/10.1016/j.envsci.2017.03.015

Al-Saidi M (2017) Urban water pricing in Yemen: a comparison of increasing block tariffs to other pricing schemes. Water Int 42:308-323. https://doi.org/10.1080/02508060.2016.1269283

Allouche J (2016) The birth and spread of IWRM - a case study of global policy diffusion and translation. Water Altern 9:412-433

Arndt C, Baker AC, Querbach T, Schultz R (2015) Indicators of regulatory policy and governance: design, methodology and key results. The Organisation for Economic Co-operation and Development (OECD), Paris

Arthington AH et al (2018) The Brisbane declaration and global action agenda on environmental flows. Front Environ Sci 6:45

Baker S (2016) Sustainable development. Routledge, New York

Bartram J, Brocklehurst C, Bradley D, Muller M, Evans B (2018) Policy review of the means of implementation targets and indicators for the sustainable development goal for water and sanitation NPJ. Clean Water 1:3. https://doi.org/10.1038/s4154 5-018-0003-0

Benson D, Gain AK, Rouillard JJ (2015) Water governance in a comparative perspective: from IWRM to a 'nexus' approach? Water Altern 8:756-773

Bertule $\mathrm{M}$ et al (2018) Monitoring water resources governance progress globally: experiences from monitoring SDG indicator 6.5.1 on integrated water resources management implementation. Water 10:1744. https://doi.org/10.3390/w10121744

Beveridge R, Monsees J (2012) Bridging parallel discourses of Integrated Water Resources Management (IWRM): institutional and 
political challenges in developing and developed countries. Water Int 37:727-743. https://doi.org/10.1080/02508060.2012.742713

Bhaduri A et al (2016) Achieving sustainable development goals from a water perspective. Front Environ Sci 4:64

Biswas AK (2004) Integrated water resources management: a reassessment. Water Int 29:248-256. https://doi.org/10.1080/02508 060408691775

Biswas AK (2008) Integrated water resources management: is it working? Int J Water Resour Dev 24:5-22. https://doi. org/10.1080/07900620701871718

Bunch MJ, Morrison KE, Parkes MW, Venema HD (2011) Promoting health and well-being by managing for social-ecological resilience: the potential of integrating ecohealth and water resources management approaches. Ecol Soc 16:6

Butterworth J, Warner J, Moriarty P, Smits S, Batchelor C (2010) Finding practical approaches to integrated water resources management. Water Altern 3:68-81

Calizaya A, Meixner O, Bengtsson L, Berndtsson R (2010) Multicriteria decision analysis (MCDA) for integrated water resources management (IWRM) in the Lake Poopo Basin, Bolivia. Water Resour Manag 24:2267-2289. https://doi.org/10.1007/s1126 9-009-9551-x

De Stefano L, Petersen-Perlman JD, Sproles EA, Eynard J, Wolf AT (2017) Assessment of transboundary river basins for potential hydro-political tensions. Glob Environ Change 45:35-46. https ://doi.org/10.1016/j.gloenvcha.2017.04.008

DeFries R, Nagendra H (2017) Ecosystem management as a wicked problem. Science 356:265

Derman B, Prabhakaran P (2016) Reflections on the formulation and implementation of IWRM in Southern Africa from a gender perspective. Water Altern 9:644-661

Dobson A (1996) Representative democracy and the environment. In: Lafferty WM, Meadowcroft J (eds) Democracy and the environment: problems and prospects. Edward Elgar, Cheltenham, pp 124-139

Dungumaro EW, Madulu NF (2003) Public participation in integrated water resources management: the case of Tanzania. Phys Chem Earth Parts A/B/C 28:1009-1014. https://doi.org/10.1016/j. pce.2003.08.042

EPA (2008) Handbook for developing watershed plans to restore and protect our waters. Environmental Protection Agency, Washington DC

EurEau (2016) Position paper "Cost recovery and water pricing". EurEau, Brussels

Evans A, Varma S (2009) Practicalities of participation in urban IWRM: perspectives of wastewater management in two cities in Sri Lanka and Bangladesh. Nat Resourc Forum 33:19-28. https ://doi.org/10.1111/j.1477-8947.2009.01205.x

Fader M, Cranmer C, Lawford R, Engel-Cox J (2018) Toward an understanding of synergies and trade-offs between water, energy, and food SDG targets. Front Environ Sci 6:112

Farinosi F et al (2018) An innovative approach to the assessment of hydro-political risk: a spatially explicit, data driven indicator of hydro-political issues. Glob Environ Change 52:286-313. https ://doi.org/10.1016/j.gloenvcha.2018.07.001

Fatch JJ, Manzungu E, Mabiza C (2010) Problematising and conceptualising local participation in transboundary water resources management: the case of Limpopo river basin in Zimbabwe. Phys Chem Earth Parts A/B/C 35:838-847. https://doi.org/10.1016/j. pce.2010.07.031

Faysse N, Errahj M, Kuper M, Mahdi M (2010) Learning to voice? The evolving roles of family farmers in the coordination of large-scale irrigation schemes in Morocco. Water Altern 3:48-67

Fritsch O, Adelle C, Benson D (2017) The EU water initiative at 15: origins, processes and assessment. Water Int 42:425-442. https ://doi.org/10.1080/02508060.2017.1330816
Fuente D, Gakii Gatua J, Ikiara M, Kabubo-Mariara J, Mwaura M, Whittington D (2016) Water and sanitation service delivery, pricing, and the poor: an empirical estimate of subsidy incidence in Nairobi, Kenya. Water Resour Res 52:4845-4862. https://doi.org/10.1002/2015WR018375

Gain AK, Giupponi C, Wada Y (2016) Measuring global water security towards sustainable development goals. Environ Res Lett 11:124015. https://doi.org/10.1088/1748-9326/11/12/124015

Gain AK, Mondal MS, Rahman R (2017) From flood control to water management: a journey of Bangladesh towards Integrated Water Resources Management. Water 9:55. https://doi. org/10.3390/w9010055

Gain AK, Rouillard JJ, Benson D (2013) Can integrated water resources management increase adaptive capacity to climate change adaptation? A critical review. J Water Resour Prot 5:11-20. https://doi.org/10.4236/jwarp.2013.54A003

Gini C (1997) Concentration and dependency ratios. Rivista di Politica Economica 87:769-789

Giordano M, Shah T (2014) From IWRM back to integrated water resources management. Int J Water Resour Dev 30:364-376. https://doi.org/10.1080/07900627.2013.851521

Giupponi C, Gain AK (2017) Integrated water resources management (IWRM) for climate change adaptation. Reg Environ Change 17:1865-1867. https://doi.org/10.1007/s10113-017-1173-x

Giupponi C, Gain AK, Farinosi F (2018) Spatial assessment of water use efficiency (SDG indicator 6.4.1) for regional policy support. Front Environ Sci 6:141. https://doi.org/10.3389/fenvs .2018 .00141

Grigg NS (2014) Integrated water resources management: unified process or debate forum? Int J Water Resour Dev 30:409-422. https://doi.org/10.1080/07900627.2013.877338

GWP (2009) A handbook for integrated water resources management in basins. Global Water Partnership (GWP) and the International Network of Basin Organizations (INBO), Stockholm

GWP (2011) Social equity and integrated water resources management. Global Water Partnership, Stockholm

GWP (2017) The need for an integrated approach. Global Water Partnership (GWP), Stockholm

Hák T, Janoušková S, Moldan B (2016) Sustainable development goals: a need for relevant indicators. Ecol Indic 60:565-573. https://doi.org/10.1016/j.ecolind.2015.08.003

Harris D, Kooy M, Jones L (2011) Analysing the governance and political economy of water and sanitation service delivery. Overseas Development Institute, London

Hering JG, Ingold KM (2012) Water resources management: what should be integrated? Science 336:1234

Huitema D, Meijerink S (eds) (2014) The politics of river basin organisations: coalitions, institutional design choices and consequences. Edward Elgar Publishing, Cheltenham. https://doi. org/10.4337/9781782549222

ICWE/WMO (1992) The Dublin Statement World Meteorological Organisation, Geneva

IUCN (1980) World Conservation Strategy International Union for the Conservation of Nature and Natural Resources (IUCN), Gland

Jager WN et al (2016) Transforming European water governance? Participation and river basin management under the EU water framework directive in 13 member states. Water. https://doi. org/10.3390/w8040156

Jimenez-Redal R, Holowko N, Almandoz J, Soriano J, Arregui F, Magrinya F (2018) Evaluating equity and inclusion in access to water and sanitation for persons living with HIV/AIDS in Wukro, Ethiopia. Water. https://doi.org/10.3390/w10091237

Kaufmann D, Kraay A, Mastruzzi M (2010) The worldwide governance indicators: methodology and analytical issues. World Bank. http://hdl.handle.net/10986/3913 
Klasen S, Schüler D (2011) Reforming the gender-related development index and the gender empowerment measure: implementing some specific proposals. Fem Econ 17:1-30. https://doi. org/10.1080/13545701.2010.541860

Kochskämper E, Challies E, Newig J, Jager NW (2016) Participation for effective environmental governance? Evidence from water framework directive implementation in Germany, Spain and the United Kingdom. J Environ Manag 181:737-748. https://doi. org/10.1016/j.jenvman.2016.08.007

Leendertse K, Mitchell S, Harlin J (2008) IWRM and the environment: a view on their interaction and examples where IWRM led to better environmental management in developing countries. Water SA 34:691-998

Lélé SM (1991) Sustainable development: a critical review. World Dev 19:607-621. https://doi.org/10.1016/0305-750X(91)90197-P

Libanio PAC (2014) The use of goal-oriented strategies in the building of water governance in Brazil. Water Int 39:401-416. https://doi. org/10.1080/02508060.2014.910433

Lorz C et al (2012) Challenges of an integrated water resource management for the Distrito Federal, Western Central Brazil: climate, land-use and water resources. Environ Earth Sci 65:1575-1586. https://doi.org/10.1007/s12665-011-1219-1

Manase G, Ndamba J, Makoni F (2003) Mainstreaming gender in integrated water resources management: the case of Zimbabwe. Phys Chem Earth Parts A/B/C 28:967-971. https://doi.org/10.1016/j. pce.2003.08.023

Mauerhofer V (2016) Public participation in environmental matters: compendium, challenges and chances globally. Land Use Policy 52:481-491. https://doi.org/10.1016/j.landusepol.2014.12.012

McCracken M, Meyer C (2018) Monitoring of transboundary water cooperation: review of sustainable development goal indicator 6.5.2 methodology. J Hydrol 563:1-12. https://doi.org/10.1016/j. jhydrol.2018.05.013

Mebratu D (1998) Sustainability and sustainable development: historical and conceptual review. Environ Impact Assess Rev 18:493520. https://doi.org/10.1016/S0195-9255(98)00019-5

Mehtonen K, Keskinen M, Varis O (2008) The Mekong: IWRM and institutions. In: Varis O, Biswas AK, Tortajada C (eds) Management of transboundary rivers and lakes. Springer, Berlin, pp 207-226https://doi.org/10.1007/978-3-540-74928-8_8

Molden D, Oweis T, Steduto P, Bindraban P, Hanjra MA, Kijne J (2010) Improving agricultural water productivity: between optimism and caution. Agric Water Manag 97:528-535. https://doi. org/10.1016/j.agwat.2009.03.023

Molle F (2009) River-basin planning and management: the social life of a concept. Geoforum 40:484-494. https://doi.org/10.1016/j. geoforum.2009.03.004

Mottaleb KA, Krupnik TJ, Keil A, Erenstein O (2019) Understanding clients, providers and the institutional dimensions of irrigation services in developing countries: a study of water markets in Bangladesh. Agric Water Manag 222:242-253. https://doi. org/10.1016/j.agwat.2019.05.038

Movik S, Mehta L, van Koppen B, Denby K (2016) Emergence, interpretations and translations of IWRM in South Africa. Water Altern 9:456-472

Munia H, Guillaume JHA, Mirumachi N, Porkka M, Wada Y, Kummu M (2016) Water stress in global transboundary river basins: significance of upstream water use on downstream stress. Environ Res Lett 11:014002

Newig J, Schulz D, Jager NW (2016) Disentangling puzzles of spatial scales and participation in environmental governance-the case of governance re-scaling through the European water framework directive. Environ Manag 58:998-1014. https://doi.org/10.1007/ s00267-016-0753-8

Nigatu Mersha A, de Fraiture C, Mehari A, Masih I, Alamirew T (2015) Integrated water resources management: contrasting principles, policy, and practice, Awash River Basin, Ethiopia. Water Policy 18:335-354. https://doi.org/10.2166/wp.2015.049

OECD (2018) OECD water governance indicator framework. The Organisation for Economic Co-operation and Development (OECD), Paris

Official Journal of the European Communities (2000) Directive 2000/60/EC of the European Parliament and of the Council of 23 October 2000 establishing a framework for Community action in the field of water policy. European Council, Luxembourg

Pastor AV, Ludwig F, Biemans H, Hoff H, Kabat P (2014) Accounting for environmental flow requirements in global water assessments. Hydrol Earth Syst Sci 18:5041-5059. https://doi.org/10.5194/ hess-18-5041-2014

Pires A, Morato J, Peixoto H, Botero V, Zuluaga L, Figueroa A (2017) Sustainability assessment of indicators for integrated water resources management. Sci Total Environ 578:139-147. https:// doi.org/10.1016/j.scitotenv.2016.10.217

Poolman M, Van De Giesen N (2006) Participation: rhetoric and reality. The importance of understanding stakeholders based on a case study in Upper East Ghana. Int J Water Resour Dev 22:561573. https://doi.org/10.1080/07900620600813191

Redclift M (2005) Sustainable development (1987-2005): an oxymoron comes of age. Sustain Dev 13:212-227. https://doi. org/10.1002/sd.281

Rennings K, Wiggering H (1997) Steps towards indicators of sustainable development: linking economic and ecological concepts. Ecol Econ 20:25-36. https://doi.org/10.1016/S0921-8009(96)00108-5

Robert KW, Parris TM, Leiserowitz AA (2005) What is sustainable development? Goals, indicators, values, and practice. Environ Sci Policy Sustain Dev 47:8-21. https://doi.org/10.1080/00139 157.2005.10524444

Rouillard JJ, Benson D, Gain AK (2014) Evaluating IWRM implementation success: are water policies in Bangladesh enhancing adaptive capacity to climate change impacts? Int J Water Resour Dev 30:515-527. https://doi.org/10.1080/07900627.2014.910756

Ruiz-Villaverde A, García-Rubio MA (2017) Public participation in European water management: from theory to practice. Water Resour Manag 31:2479-2495. https://doi.org/10.1007/s1126 9-016-1355-1

Sachs JD (2012) From millennium development goals to sustainable development goals. Lancet 379:2206-2211. https://doi. org/10.1016/S0140-6736(12)60685-0

Saha AK, Setegn SG (2015) Ecohydrology: understanding and maintaining ecosystem services for IWRM. In: Setegn SG, Donoso MC (eds) Sustainability of integrated water resources management: water governance, climate and ecohydrology. Springer International Publishing, Cham, pp 121-145. https://doi. org/10.1007/978-3-319-12194-9_8

Saravanan VS, McDonald GT, Mollinga PP (2009) Critical review of integrated water resources management: moving beyond polarised discourse. Nat Resour Forum 33:76-86. https://doi.org/10. 1111/j.1477-8947.2009.01210.x

Sartori G (1970) Concept misformation in comparative politics. Am Political Sci Rev 64:1033-1053. https://doi.org/10.2307/1958356

Senecal C, Madramootoo CA (2013) Tools for the implementation of integrated water resources management (IWRM) in the Caribbean. Water Policy 15:859-870. https://doi.org/10.2166/ wp.2013.016

Sjödin J, Zaeske A, Joyce J (2016) Pricing instruments for sustainable water management. Stockholm International Water Institute (SIWI), Stockholm

Smith M, Clausen TJ (2017) Revitalising IWRM for the 2030 Agenda. Background paper for the high-level panel on IWRM, XVI IWRA World Water Congress, Cancun Mexico. IWRA World Water Congress, Cancun, Mexico 
Sokolov V (2006) Experiences with IWRM in the Central Asia and Caucasus regions. Water Int 31:59-70. https://doi. org/10.1080/02508060608691915

Sood A et al (2017) Global environmental flow information for the sustainable development goals. International Water Management Institute Colombo, Sri Lanka

Steurer R, Hametner M (2013) Objectives and indicators in sustainable development strategies: similarities and variances across Europe. Sustain Dev 21:224-241. https://doi.org/10.1002/sd.501

Toan TD (2016) Water pricing policy and subsidies to irrigation: a review. Environ Process 3:1081-1098. https://doi.org/10.1007/ s40710-016-0187-6

UN-Water (2017a) Integrated monitoring guide for sustainable development goal 6 on water and sanitation: targets and global indicators. UN-Water, Geneva

UN-Water (2017b) Step-by-step monitoring methodology for indicator 6.5.2. United Nations

UN-Water (2017c) Step-by-step monitoring methodology for SDG indicator 6.5.1. United Nations

UN-Water (2018) Sustainable development goal 6 synthesis report on water and sanitation. UN-Water, Geneva

UN (2017) Revised list of global sustainable development goal indicators. United Nations, New York

UNCED (1992) Agenda 21: programme of action for sustainable development, United Nations Conference on Environment \& Development. United Nations, Rio de Janerio, Brazil

UNEP-WCMC (2014) Measuring ecosystem services: guidance on developing ecosystem services indicators. United Nations Environment Programme World Conservation Monitoring Centre (UNEP-WCMC), Nairobi

UNEP (2018) Progress on integrated water resources management: global baseline for SDG 6 indicator 6.5.1-degree of IWRM implementation. United Nations Environment Programme, Nairobi

UNESCO (2009) Introduction to the IWRM guidelines at river basin level. United Nations Educational, Scientific and Cultural Organization, Paris

Varis O, Rahaman MM, Stucki V (2008) The rocky road from integrated plans to implementation: lessons learned from the Mekong and Senegal river basins. Int J Water Resour Dev 24:103-121. https://doi.org/10.1080/07900620701723307

Veettil PS, Speelman S, Frija A, Buysse J, Mondelaers K, van Huylenbroeck G (2011) Price sensitivity of farmer preferences for irrigation water-pricing method: evidence from a choice model analysis in Krishna River basin, India. J Water Resour Plan Manag 137:205-214. https://doi.org/10.1061/(ASCE)WR.19435452.0000103

Voulvoulis N, Arpon KD, Giakoumis T (2017) The EU water framework directive: from great expectations to problems with implementation. Sci Total Environ 575:358-366. https://doi. org/10.1016/j.scitotenv.2016.09.228

Wang Y, Chen S (2014) Breaking the dilemma of agricultural water fee collection in China. Water Policy 16:773-784. https://doi org/10.2166/wp.2014.073

WCED (1987) Our common future. World commission on environment and development. Oxford University Press, Oxford

WEF (2018) Harnessing artificial intelligence for the Earth. World Economic Forum (WEF), Cologny

Wester P, Hoogesteger J, Vincent L (2009) Local IWRM organizations for groundwater regulation: the experiences of the Aquifer Management Councils (COTAS) in Guanajuato, Mexico. Nat Resour Forum 33:29-38. https://doi.org/10.111 1/j.1477-8947.2009.01206.x

WRI (2018) Environmental democracy index. https://environmentalde mocracyindex.org/. Accessed 4 Jan 2019

Yu H, Edmunds M, Lora-Wainwright A, Thomas D (2014) From principles to localized implementation: villagers' experiences of IWRM in the Shiyang River basin, Northwest China. Int J Water Resour Dev 30:588-604. https://doi.org/10.1080/07900 627.2014.917949

Yu HH, Edmunds M, Lora-Wainwright A, Thomas D (2016) Governance of the irrigation commons under integrated water resources management - a comparative study in contemporary rural China. Environ Sci Policy 55:65-74. https://doi.org/10.1016/j.envsc i.2015.08.001

Zeitoun M, Goulden M, Tickner D (2013) Current and future challenges facing transboundary river basin management. Wiley Interdiscip Rev Clim Change 4:331-349. https://doi.org/10.1002/ wcc. 228

Publisher's Note Springer Nature remains neutral with regard to jurisdictional claims in published maps and institutional affiliations. 